\title{
Kemampuan Memecahkan Masalah Rangkaian Arus Searah Pada Pembelajaran Berbasis Masalah Disertai Penilaian Formatif
}

\author{
Ari Hindriyani ${ }^{1}$, Sentot Kusairi ${ }^{1}$, Lia Yuliati ${ }^{1}$ \\ ${ }^{1}$ Pendidikan Fisika-Universitas Negeri Malang
}

\begin{tabular}{l}
\hline \hline INFO ARTIKEL \\
\hline Riwayat Artikel: \\
Diterima: 02-01-2020 \\
Disetujui: 15-09-2020 \\
\hline Kata kunci: \\
problem solving skills; \\
direct current circuit; \\
problem based learning; \\
formative assessment; \\
kemampuan memecahkan masalah; \\
rangkaian arus searah; \\
pembelajaran berbasis masalah; \\
penilaian formatif
\end{tabular}

\author{
Alamat Korespondensi: \\ Ari Hindriyani \\ Pendidikan Fisika \\ Universitas Negeri Malang \\ Jalan Semarang 5 Malang \\ E-mail: ari.hindriyani.1703218@student.um.ac.id
}

Materi fisika tentang rangkaian listrik arus searah yang meliputi materi hukum Ohm, arus, tegangan, hambatan, energi, dan daya listrik yang perlu dikuasai peserta didik (Puente \& Jansen, 2017). Ternyata masih banyak peserta didik yang mengalami kesulitan dalam memahami konsep rangkaian listrik arus searah, hal tersebut disebabkan karena karakteristik materi sulit dipahami dengan konsep abstrak, hukum, dan persamaan. (Taufik \& Kristanto, 2018). Kesulitan yang dialami peserta didik antara lain karena peserta didik tidak dapat menganalogikan dan menggunakan permodelan yang tepat tentang konsep rangkaian listrik arus searah pada suatu permasalahan (Permatasari \& Siregar, 2014). Juga kesulitan dalam menganalisis penggunaan hukum Ohm untuk menyelesaikan masalah rangkaian listrik yang lebih kompleks (Riantoni, Yuliati, Mufti, 2017).

Kesulitan yang memengaruhi peserta didik dalam menyelesaikan masalah listrik arus searah antara lain masih lemahnya peserta didik dalam penerapan konsep untuk proses memecahkan masalah (Azizah \& Yuliati, 2015). Kemampuan memecahkan masalah adalah elemen penting dalam pembelajaran fisika (Docktor, Strand, Mestre, \& Ross, 2015). Kemampuan memecahkan masalah adalah kemampuan menyusun strategi penyelesaian masalah dengan menggunakan prinsip atau konsep utama yang dihubungkan dengan konteks atau kondisi dan diterapkan dengan prosedur serta ide-idenya (Docktor \& Mestre, 2014). Kemampuan memecahkan masalah, seorang individu tidak hanya perlu berpikir, tetapi mereka juga harus berpikir kritis untuk dapat melihat masalah dan berpikir secara kreatif untuk dapat menyelesaikan masalah (Apriyani, Ramalis, Suwarma, 2019). 
Tujuan penting pembelajaran fisika adalah dapat menjelaskan fenomena (Vlassi \& Karaliota, 2013) dan mengantarkan peserta didik dalam menguasaai konsep-konsep dasar fisika sehingga peserta didik mampu menerapkannya dalam memecahkan masalah (Rahmiati, Musdi, Fauzi, 2018). Pembelajaran Fisika membutuhkan kemampuan memecahkan masalah yang baik dari peserta didik sebagai acuan untuk memecahkan masalah dalam pembelajaran Fisika (Azizah \& Yuliati, 2015). Kemampuan memecahkan masalah peserta didik merupakan dasar peserta didik untuk memahami permasalahan-permasalahan dalam Fisika (Suminten, 2015). Kemampuan memecahkan masalah aspek yang diperlukan untuk mewujudkan hasil pembelajaran yang lebih baik (Doyan \& Sukmantara, 2014). Kemampuan memecahkan masalah sangat penting dimiliki oleh setiap individu. dikarenakan penguasan konsep dapat bermanfaat dan meningkatkan kemampuan memecahkan suatu masalah yang kontekstual (Silaban, 2014).

Model pembelajaran yang efisien dan bermakna untuk sukses dalam memecahkan masalah bertujuan untuk mempersiapkan siswa yang dapat berpikir secara konseptual, menyelesaikan masalah yaitu pembelajaran berbasis masalah (Barakat, 2003). Pembelajaran berbasis masalah salah adalah pembelajaran yang kolaboratif, digunakan untuk menjawab pertanyaan yang lebih besar atau memecahkan masalah dunia nyata, yang bermakna melibatkan pembelajaran keterampilan baru dan mengeksplorasi perspektif dan ide-ide baru yang dapat diterapkan untuk pengalaman masa depan. (Davis, 2017). Penerapan pembelajaran berbasis masalah dapat meningkatkan kemampuan memecahkan masalah kelistrikan pada kategori sedang dan tinggi (Yusofa, Yuliati, Muhardjito, 2019) pencapaian akademik pada beberapa konsep Fisika lebih tinggi (Yuliati, Riantoni, Mufti, 2018). Mampu memecahkan kode, menafsirkan, dan memperoleh informasi representasi yang sesuai untuk menyelesaikan masalah yang diberikan. (De Cock, 2012) meningkatkan kinerja pemecahan masalah. (Sezgin Selçuk \& Çalýskan, 2008). Langkah-langkah pembelajaran berbasis masalah meliputi lima langkah, yaitu orientasi masalah, mengorganisasikan pembelajaran, merencanakan penyelesaian, menjalankan rencana, dan mengevaluasi penyelesaiannya (Docktor et al., 2015).

Tingkat keberhasilan kemampuan peserta didik memecahkan masalah pada pembelajaran berbasis masalah dapat diukur dari hasil penilaian (Wolterinck et al., 2016). Penilaian Formatif dapat memberikan umpan balik untuk pendidik dan peserta didik tentang pembelajarannya (Owen, 2016). Dengan penilaian formatif dapat memotivasi peserta didik dalam belajar saat diberikan balikan atas pembelajaran yang telah dilakukan (Buchholtz et al., 2018). Pendidik dapat merencanakan pembelajaran berikutnya yang lebih baik (Ford-connors et al., 2016). Penilaian formatif dilaksanakan secara langsung saat pembelajaran dan dapat membantu peserta didik dalam mengusai konsep (Wolterinck, Kippers, Schildkamp, \& Poortman 2016). Dengan memberikan petunjuk langkah-langkah pada balikan pada peserta didik dapat meningkatkan pemahaman yang memungkinkan peserta didik dapat terlibat dalam memecahkan masalah (Andersson \& Palm, 2017). Penelitian ini bertujuan untuk mengetahui pengaruh pembelajaran berbasis masalah disertai penilaian formatif terhadap penguasaan konsep dan kemampuan memecahkan masalah peserta didik SMA/MA dalam materi rangkaian arus searah. secara kualitatif dan kuantitaif.

\section{METODE}

Penelitian ini menggunakan satu variabel bebas yaitu model pembelajaran berbasis masalah disertai penilaian formatif dan dua variabel terikat, yaitu penguasaan konsep dan kemampuan memecahkan masalah. Rancangan penelitian ini menggunakan mixed method dengan desain embedded experimental (Creswell, 2007). Penelitian ini diawali dengan pemberian soal pre-test dan wawancara sebelum perlakuan kemudian diberikan perlakuan dalam proses pembelajaran berupa model pembelajaran berbasis masalah disertai penilaian formatif dan diakhir dengan pemberian soal post-test dan wawancara setelah perlakuan untuk mengetahui kemampuan memecahkan masalah peserta didik sebelum dan sesudah perlakuan. Model pembelajaran berbasis masalah dengan lima langkah, yaitu (1) orientasi peserta didik pada masalah, (2) mengoorganisasi peserta didik untuk belajar, (3) membimbing percobaan secara individu atau kelompok, (4) mengembangkan dan menyajikan hasil karya, dan (5) menganalisis dan mengevaluasi proses pemecahan masalah. Dengan disertai penilaian formatif dalam pembelajaran dengan tahapan identifikasi tujuan, rich conversation, terjadinya interaksi antara guru dan siswa, merespon kelemahan peserta didik dan feedback. Desain penelitian ini dirangkai sebagaimana tampak pada gambar 1.

Populasi dalam penelitian ini adalah semua siswa kelas Kelas XII peminatan MIPA di MAN Kota Pasuruan pada semester ganjil tahun peklajaran 2019/2020. Teknik pengambilan sampel penelitian ini adalah dengan Purposive sampling. Teknik pengambilan sampel ini karena tidak memungkinkan perubahan pembentukan siswa di kelas yang ada jika dipilih secara individual sampel individu. Sehingga satu kelas diambil untuk digunakan sebagai kelompok subjek penelitian.

Instrumen untuk kemampuan pemecahan masalah yang digunakan berupa instrumen perlakuan dan instrument pengukuran. Tes kemampuan pemecahan masalah diberikan dalam dua uji coba. Pretest dan posttest dalam. Instrumen ini berupa soal pilihan ganda disertai alasan berupa soal memecahkan masalah 5 butir soal Setiap item terdiri dari lima indikator penyelesaian masalah. Dalam penelitian ini dilakukan dalam dua Jam Pelajaran setiap pertemuan selama enam kali pertemuan. Kegiatan penelitian terinci terdiri dari pertemuan pertama untuk pretest, pertemuan kedua pembelajaran materi Arus dan Tegangan Listrik. Pertemuan ketiga pembelajaran materi Hambatan penghantar listrik dan Hukum I Kirchoff rangkaian listrik, pertemuan keempat pembelajaran materi energi dan daya listrik, dan pertemuan keenam untuk kegiatan posttest. 
Instrumen Pengukuran berupa soal pretest yang disampaikan ke peserta didik sebelum perlakuani dan soal posttest yang disampaikan ke peserta didik sebelum perlakuan. Instrumen ini berupa soal pilihan ganda disertai alasan berupa soal memecahkan masalah lima butir soal. Tiap soal dinilai menurut rubrik penilaian sesuai aspek kemampuan peserta didik. Dari rubrik peskoran kemampuan memecahkan masalah pada tiap butir soal diperoleh Hasil Uji coba Butir Soal ditunjukkan pada tabel 2.

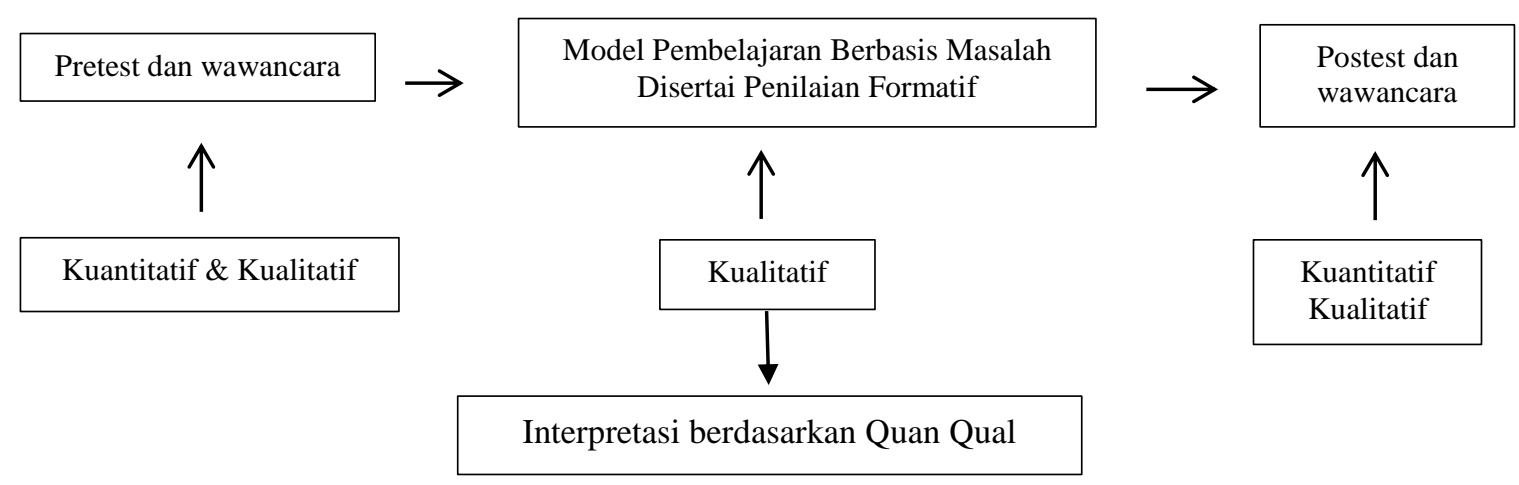

Gambar 1. Desain Penelitian

Tabel 1. Rubrik Penskoran Kemampuan Memecahkan Masalah Pada Butir Soal

\begin{tabular}{lc}
\hline \multicolumn{1}{c}{ Deskripsi Jawaban } & Skor \\
\hline Jawaban benar, alasan sesuai permasalahan dan lengkap & 5 \\
Jawaban benar, alasan sesuai permasalahan namun belum lengkap & 4 \\
Jawaban benar, alasan sesuai permasalahan namun ada kelalaian & 3 \\
Jawaban salah, alasan sesuai permasalahan & 2 \\
Jawaban salah, alasan tidak sesuai pemasalahan & 1 \\
\hline
\end{tabular}

Tabel 2. Hasil Uji Coba Soal Kemampuan Memecahkan Masalah

\begin{tabular}{|c|c|c|c|c|}
\hline Nomor Soal & $\begin{array}{c}\text { Validitas } \\
r_{\text {table }}=0,1625\end{array}$ & Reliabilitas & Taraf Kesukaran & Daya Beda \\
\hline 1 & $\begin{array}{l}\mathrm{r}_{\text {hitung }}=0,444 \\
(\text { Valid })\end{array}$ & $\mathrm{r}=0,583$ (cukup) & $\begin{array}{l}\mathrm{TK}=0,43 \\
\text { (sedang) }\end{array}$ & $\begin{array}{l}\mathrm{D}=0,56 \\
\text { (Baik) }\end{array}$ \\
\hline 2 & $\begin{array}{l}\mathrm{r}_{\text {hitung }}=0,201 \\
\text { (Valid) }\end{array}$ & $\mathrm{r}=0,630($ tinggi $)$ & $\begin{array}{l}\mathrm{TK}=0,125 \\
\text { (sukar) }\end{array}$ & $\begin{array}{l}\mathrm{D}=0,21 \\
\text { (cukup) }\end{array}$ \\
\hline 3 & $\begin{array}{l}\mathrm{r} \text { hitung }=0,261 \\
(\text { Valid })\end{array}$ & $\mathrm{r}=0,620($ tinggi $)$ & $\begin{array}{l}\mathrm{TK}=0,31 \\
\text { (sedang) }\end{array}$ & $\begin{array}{l}\mathrm{D}=0,33 \\
\text { (cukup) }\end{array}$ \\
\hline 4 & $\begin{array}{l}\mathrm{r} \text { hitung }=0,464 \\
\text { (Valid) }\end{array}$ & $\mathrm{r}=0,583$ (cukup) & $\begin{array}{l}\mathrm{TK}=0,37 \\
\text { (sedang) }\end{array}$ & $\begin{array}{l}\mathrm{D}=0,51 \\
\text { (baik) }\end{array}$ \\
\hline 5 & $\begin{array}{l}\mathrm{r}_{\text {hitung }}=0,326 \\
\text { (Valid) }\end{array}$ & $\mathrm{r}=0,620($ tinggi $)$ & $\begin{array}{l}\mathrm{TK}=0,145 \\
\text { (sukar) }\end{array}$ & $\begin{array}{l}\mathrm{D}=0,21 \\
\text { (cukup) }\end{array}$ \\
\hline
\end{tabular}

Analisis data kuantitatif digunakan untuk mengetahui besarnya pengaruh pembelajaran berbasis masalah disertai penilaian terhadap kemampuan memecahkan masalah pada materi rangkaian arus searah. Sumber data dari skor pretest dan posttest yang dianalisis dengan dihitung menggunakan uji statistic deskripsi, uji effect size dan N-Gain.

\section{HASIL}

Deskripsi data statistik digunakan untuk mengetahui perubahan yang terjadi pada Kemampuan Memecahkan Masalah Rangkaian Arus Searah Sebelum dan sesudah perlakuan Pembelajaran Berbasis Masalah Disertai Penilaian Formatif. Berikut grafik perubahan terjadi pada Kemampuan Memecahkan Masalah Rangkaian Arus Searah Sebelum dan sesudah Pembelajaran Berbasis Masalah Disertai Penilaian Formatif. 


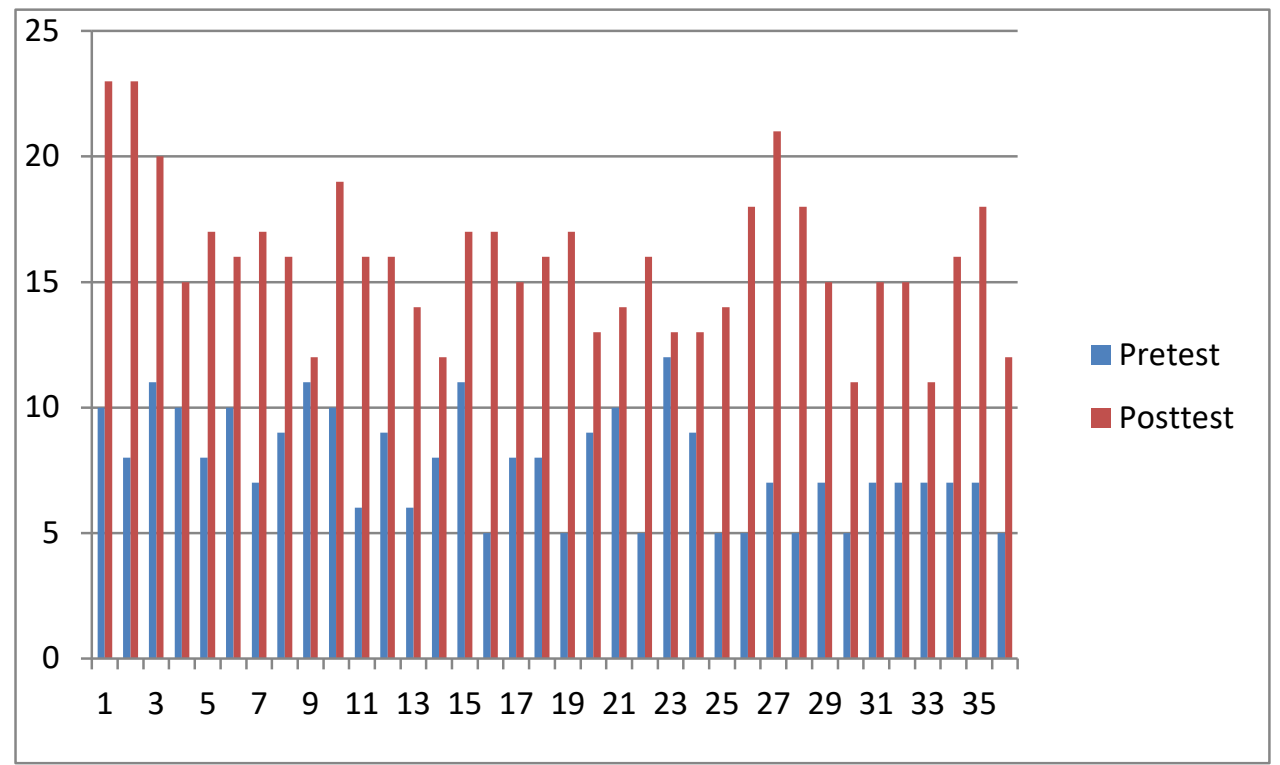

\section{Gambar 2. Grafik Perubahan yang terjadi pada Kemampuan Memecahkan Masalah Rangkaian Arus Searah Sebelum dan sesudah Pembelajaran Berbasis Masalah Disertai Penilaian Formatif}

Dari grafik tersebut diperoleh skor postes lebih tinggi dibandingkan skor pretes, hal tersebut menunjukkan bahwa terjadi peningkatan kemampuan memecahkan masalah sesudah pembelajaran berbasis masalah disertai penilaian formatif.

Tabel 3. Tabel Uji Normalitas Kemampuan Memecahkan Masalah

\begin{tabular}{lcc}
\hline Shafiro-wilk & Pretest & Postest \\
\hline Statistic & 0,925 & 0,952 \\
df & 36 & 36 \\
Signifikansi & 0,071 & 0,122 \\
\hline
\end{tabular}

Data Kemampuan Memecahkan Masalah dianggap terdistribusi normal dengan nilai signifikasi dari nilai pretes adalah 0,071 dan postes 0,122 . Keduanya dapat dinyatakan terdistribusi normal karena mempunyai nilai > 0,05. Uji-t, N-gain score, dan effect size Uji Normalitas dari Kemampuan Memecahkan Masalah peserta didik.

Tabel 4. Tabel Uji-t, N-gain score, dan effect size Kemampuan memecahkan masalah

\begin{tabular}{cc}
\hline Kategori & Nilai \\
\hline $\mathrm{t}$ & $-13,957$ \\
signifikansi & 0,000 \\
N-gain score & 0,47 \\
effect size & 1,685 \\
\hline
\end{tabular}

Hasil uji-t berpasangan mempunyai signifikasi 0,00 menunjukkan bahwa Pembelajaran Berbasis Masalah Disertai Penilaian Formatif meningkatkan hasil yang sifgnifikansi terhadap Kemampuan Memecahkan Masalah Rangkaian Arus Searah. Untuk N-gain score dengan nilai 0,47 menunjukkan bahwa kemampuan memecahkan masalah Rangkaian Arus Searah setelah pembelajaran Berbasis Masalah Disertai Penilaian Formatif pada kategori sedang. Serta Effect size dengan nilai 1,685 menunjukkan pembelajaran Berbasis Masalah Disertai Penilaian Formatif memberikan pengaruh yang kuat pada Kemampuan Memecahkan Masalah Rangkaian Arus Searah

\section{PEMBAHASAN}

Soal kemampuan memecahkan masalah arus searah diukur dengan menggunakan lima butir soal dalam bentuk pilihan ganda disertai dengan alasan. Soal tersebut digunakan dalam pretes dan postes pada kelas yang telah dipilih. Berdasarkan hasil statistik deskriptif diperoleh untuk $\mathrm{N}$-gain score dengan nilai 0,47 menunjukkan bahwa kemampuan memecahkan masalah Rangkaian Arus Searah setelah pembelajaran berbasis masalah disertai penilaian formatif pada kategori sedang. Effect size dengan nilai 1,685 menunjukkan pembelajaran berbasis masalah disertai penilaian formatif memberikan pengaruh yang kuat 
pada kemampuan memecahkan masalah rangkaian arus searah. Pembelajaran berbasis masalah meningkatkan kemampuan pemecahan masalah (Apriyani, Ramalis, Suwarma, 2019). Pembelajaran berbasis masalah mampu meningkatkan kemampuan peserta didik dalam memecahkan masalah-masalah fisika (Setyonoaji, Diantoro, Sutopo, 2017) serta membantu peserta didik membangun pemahaman dan pengetahuan mereka yang mendalam tentang rangkaian listrik (Papadimitriou, 2012).

Berdasarkan hasil analisis data penelitian dari data nilai postes Kemampuan Memecahkan Masalah peserta didik diperoleh rata-rata skor tertinggi pada soal nomor 1 tentang rangkaian lampu. Butir soal nomor 1 terkait dengan rangkaian lampu terhandap nyala lampu. Berdasarkan analisis data penelitian dari data nilai postes Kemampuan Memecahkan Masalah peserta didik diperoleh rata-rata skor terendah pada soal nomor 5 tentang hukum I Kirchoff. Butir soal nomor 5 terkait dengan analisis aliran arus listrik. Terdapat kesulitan peserta didik dalam memecahkan masalah pengaruh potensial listrik pada arus litsrik (Engelhardt \& Beichner, 2004).

Berdasarkan nilai rata-rata postes kemampuan memecahkan masalah 15 dari nilai maksimum 25 menunjukkan peserta didik cenderung jawaban benar, alasan sesuai permasalahan, namun ada kelalaian. Hal ini menyebabkan peserta didik tidak memperoleh hasil maksimal. Salah satu faktor yang memengaruhi masih rendahnya peserta didik dalam menyelesaikan permasalahan listrik dinamis adalah masih lemahnya kemampuan peserta didik dalam menerapkan konsep dalam proses pemecahan masalah (Riantoni, Yuliati, Mufti, 2017). Kemampuan pemecahan masalah peserta terdiri dalam tahap memahami masalah pada tingkat kemampuan tinggi, tahap merencanakan penyelesaian masalah pada tingkat kemampuan sedang, pada tahap melaksanakan penyelesaian masalah pada tingkat kemampuan sedang dan tahap memeriksa kembali solusi berada pada tingkat kemampuan sangat rendah (Wahyuni, Irianti, \& Azhar, 2015).

Hasil penelitian ini memperoleh hasil bahwa pembelajaran berbasis masalah disertasi penilaian formatif meningkatkan kemampuan memecahkan masalah peserta didik. Pembelajaran berbasis pemecahan masalah untuk meningkatkan keterampilan pemecahan masalah peserta didik (Karatas \& Baki, 2013). Penilaian formatif berbasis pemecahan masalah memberikan peran penting dalam pra-penilaian, pertanyaan umpan balik formatif, dan contoh pekerjaan bagi peserta didik (Swan, Malcolm, \& Foster, 2016).

\section{SIMPULAN}

Berdasarkan dari analisis data kualitatif dan kuantitatif diperoleh hasil bahwa pembelajaran berbasis masalah disertai penilaian formatif memberikan hasil yang lebih baik terhadap kemampuan memecahkan masalah rangkaian arus searah. Selain itu, pembelajaran berbasis masalah disertai penilaian formatif memberikan pengaruh yang kuat dan dampak positif pada kemampuan memecahkan masalah rangkaian arus searah. Di samping itu, masih diperlukan peningkatan kemampuan memecahkan masalah peserta didik pada materi fisika yang lainnya dengan menggunakan model pembelajaran berbasis masalah dengan disertai penilaian formatif yang lebih kompleks dari data yang lebih lengkap.

\section{DAFTAR RUJUKAN}

Andersson, C., \& Palm, T. (2017). Characteristics of Improved Formative Assessment Practice. Education Inquiry, 8(2), 104122. https://doi.org/10.1080/20004508.2016.1275185

Apriyani, R., Ramalis, T. R., \& Suwarma, I. R. (2019). Analyzing Student's Problem Solving Abilities of Direct Current Electricity in STEM-based Learning. Journal of Science Learning, 2(3), 85-91. https://doi.org/10.17509/jsl.v2i3.17559

Azizah, R., \& Yuliati, L. (2015). Kesulitan Pemecahan Masalah Fisika pada Siswa SMA. Jurnal Penelitian Fisika dan Aplikasinya (JPFA), 5(2), 44-50.

Barakat, H. (2003). Students' Problem Solving Strategies in Stoichiometry and their Relationships to Conceptual Understanding and Learning Approaches. Electronic Journal of Science Education, 7(3), 37-39.

Buchholtz, N. F., Krosanke, N., Orschulik, A. B., \& Vorhölter, K. (2018). Combining and Integrating Formative and Summative Assessment in Mathematics Teacher Education. ZDM - Mathematics Education, 50(4), 715-728. https://doi.org/10.1007/s11858-018-0948-y

Creswell, J. W. (2007). Qualitative Enquiry \& Research Design, Choosing Among Five Approaches. In SAGE: Vol. 2nd ed. https://doi.org/10.1016/j.aenj.2008.02.005

Davis, A. (2017). Project-Based Learning in Distance Learning High School Courses. In SIT Digital Collections.

De Cock, M. (2012). Representation Use and Strategy Choice in Physics Problem Solving. Physical Review Special Topics Physics Education Research, 8(2), 1-15. https://doi.org/10.1103/PhysRevSTPER.8.020117

Docktor, J. L., \& Mestre, J. P. (2014). Synthesis of Discipline-Based Education Research in Physics. Physical Review Special Topics - Physics Education Research, 10(2), 1-58. https://doi.org/10.1103/PhysRevSTPER.10.020119

Docktor, J. L., Strand, N. E., Mestre, J. P., \& Ross, B. H. (2015). Conceptual Problem solving in High School Physics. Physical Review Special Topics - Physics Education Research, 11(2), 1-13. https://doi.org/10.1103/PhysRevSTPER.11.020106

Doyan, A., \& Sukmantara. (2014). Pengembangan Web Intranet Fisika untuk Meningkatkan Penguasaan Konsep dan Kemampuan Pemecahan Masalah Siswa SMK. Jurnal Pendidikan Fisika Indonesia, 10(2), 117-127.

Engelhardt, P. V., \& Beichner, R. J. (2004). Students' Understanding of Direct Current Resistive Electrical Circuits. American Journal of Physics, 72(1), 98-115. https://doi.org/10.1119/1.1614813 
Ford-connors, E., Robertson, D. A., \& Paratore, J. R. (2016). Classroom Talk as (In)Formative Assessment. Voices from the Middle, 23(3).

Karatas, I., \& Baki, A. (2013). The Effect of Learning Environments Based on Problem Solving on Students' Achievements of Problem Solving. International Electronic Journal of Elementary Education, 5(3), 249-267.

Owen, L. (2016). The Impact of Feedback as Formative Assessment on Student Performance. International Journal of Teaching and Learning in Higher Education, 28(2), 168-175.

Papadimitriou, A. (2012). A Scenario-Based Learning of Electrical Circuits. Journal of Education and Practice, 3(7), 27-40.

Permatasari, D. S., \& Siregar, N. (2014). Pengaruh Model Pembelajaran Problem Solving terhadap Hasil Belajar Siswa pada Materi Listrik Dinamis di Kelas X SMA Mulia Medan TP. 2012/2013. Jurnal Inpafi, 2(3), 190-197.

Puente, S. M. G., \& Jansen, J. W. (2017). Exploring Students' Engineering Designs Through Open-Ended Assignments. European Journal of Engineering Education, 42(1), 109-125. https://doi.org/10.1080/03043797.2016.1220510

Rahmiati, R., Musdi, E., \& Fauzi, A. (2018). Pengembangan Perangkat Pembelajaran Matematika Berbasis Discovery Learning untuk Meningkatkan Kemampuan Pemecahan Masalah Siswa Kelas VIII SMP. Mosharafa: Jurnal Pendidikan Matematika, 6(2), 267-272. https://doi.org/10.31980/mosharafa.v6i2.314

Riantoni, C., Yuliati, L., \& Mufti, N. (2017). Kemampuan Pemecahan Masalah Materi Listrik Dinamis pada Pembelajaran Guided Inquiry Berbantuan PhET pada Mahasiswa S1 Pendidikan Fisika. Jurnal Riset dan Kajian Pendidikan Fisika, 4(1), 40. https://doi.org/10.12928/jrkpf.v4i1.6468

Setyonoaji, D. P., Diantoro, M., \& Sutopo. (2017). Pengaruh Problem Based Learning terhadap Penguasaan Konsep Dalam Pembelajaran Fisika Siswa SMA. Prosiding TEP \& PDs, 223-230.

Sezgin Selçuk, G., \& Çalýskan, S. (2008). The Effects of Problem Solving Instruction on Physics Achievement, Problem Solving Performance and Strategy Use. Latin-American Journal of Physics Education, 2 (3), 1.

Silaban, B. (2014). Hubungan Antara Penguasaan Konsep Fisika dan Kreativitas dengan Kemampuan Memecahkan Masalah pada Materi Pokok Listrik Statis. Penelitian Bidang Pendidikan, 20(1), 65-75.

Suminten, N. (2015). Strategi Pembelajaran Relating-Experiencing-Applying-Cooperating-Transferring (REACT) dengan Pendekatan Inkuiri untuk Mengurangi Miskonsepsi Fisika Siswa. Jurnal Fisika dan Pendidikan Fisika, 1(2).

Swan, Malcolm and Foster, C. (2016). Formative Assessment Lessons for Concept Development and Problem Solving. International Congress on Mathematical Education Hamburg, July, 24-31.

Taufik, M., \& Kristanto, A. (2018). Pengembangan Mobile Learning Berbasis Aplikasi Android Mata Pelajaran Fisika Materi Listrik Arus Searah Kelas XI SMK Negeri 2 Kediri. Jurnal Mahasiswa Teknologi Pendidikan, 9(2), 1-8.

Vlassi, M., \& Karaliota, A. (2013). The Comparison between Guided Inquiry and Traditional Teaching Method. A Case Study for the Teaching of the Structure of Matter to $8^{\text {th }}$ Grade Greek Students. Procedia - Social and Behavioral Sciences, 93, 494-497. https://doi.org/10.1016/j.sbspro.2013.09.226

Wahyuni, S., Irianti, M., \& Azhar, A. (2015). Problem Solving Skill of Student with the Implementation of Modeling Instruction in Dynamic Electric Concept. Program Studi Pendidikan Fisika FKIP Universitas Riau, Pekanbaru, 1-10.

Wolterinck, C. H. D., Kippers, W. B., Schildkamp, K., \& Poortman, C. L. (2016). Factors Influencing the Use of Formative Assessment in the Classroom Session: Future Trends in Educational Assessment in the Netherlands. AERA, WASHINGTON, . https://www.utwente.nl/en/bms/elan/datateams/Presentations/AERA 2016 Factors FA in classroom.pdf

Yuliati, L., Riantoni, C., \& Mufti, N. (2018). Problem Solving Skills on Direct Current Electricity Through Inquiry-Based Learning with PhET simulations. International Journal of Instruction, 11(4), 123-138. https://doi.org/10.12973/iji.2018.1149a

Yusofa, D., Yuliati, L., \& Muhardjito. (2019). Pengaruh Thinking Maps Dalam Pembelajaran Berbasis Masalah terhadap Kemampuan Pemecahan Masalah dan Penguasaan Konsep Siswa. Jurnal Pendidikan: Teori, Penelitian, dan Pengembangan, 4(1), 46-50. 